\title{
Ornamental art of Indigenous People of the Arctic: Traditions and the Present (Based on the Evens and Evenki)
}

\author{
Galina N. Varavina* \\ Institute for Humanities Research \\ and Indigenous Studies of the North SB RAS \\ 1 Petrovskogo Str., Yakutsk, Russia, \\ Sakha Republic (Yakutia), 677027, Yakutsk
}

Received 27.03.2016, received in revised form 28.05.2016, accepted 30.08.2016

The present research studies the ornamental traditions of the indigenous peoples of the Arctic. It suggests a general typological characteristic of the traditional ornament of the Northern Tungus, Evens and Evenki. Since the dawn of time, they have been unique representatives of the Northern nomadic peoples, representing the Northeast division of the Tungus, belonging to Siberian-Manchurian ethnogenetic branch. In the course of long historical development, the Northern peoples created a number of works of decorative art, forming a unique cultural heritage of the circumpolar region, and making a cumulative contribution into the world culture treasury. Circumpolar culture of the nomads has developed a complicated system for harmonious existence of nature and man. This knowledge of the Northern nomads has been passed on from father to son, transmitted through the works of culture and art, being unique models of arts and crafts of the ethnos. The figurative "language" of the ornament of the Northern peoples is rich and multi-faceted, incorporating experience of interaction between nature and man. The Tungus ornament is one of the phenomena of the Even and Evenki national culture, reflecting its originality and peculiar features. The Tungus ornament is specific for expressing the nomadic culture, traditional way of life and peculiar picture of the world. It is distinguished with artistic and stylistic features along with the sacral and semantic content. The ornamental motives have been considered sacral, as they serve as a protective amulet. It should be noted that the ornament art is one of the most original elements of ethnic culture, vulnerable to changes much less than the routine objects they decorate. However, the Tungus ornament, and that of the Evens and Evenki in particular, remains an understudied area which has not undergone a comprehensive and deep analysis, especially on the semiotic and linguistic levels. For this reason, the present research drives a really acute problem. Besides, with the currently growing interest to the culture of autochthonic ethnicities, their stories and values, the traditional ornament may be classified as "raw material of the future". Today, the scope of using forms, compositions, and elements of the traditional ornament in various areas of culture is extending such as to the design of trademark, decoration etc. So, Buryat Institute of Natural Science is working on a computer database of the traditional ornaments of the Mongol speaking peoples, which becomes a peculiar encyclopaedia of symbols, which may be used for creating new patterns based on the existing prototypes. For this reason, at the present stage the traditional ornament continues its development today. It is important to note that the traditional ornamental culture of the small-numbered indigenous peoples of the North and Siberia, based on mythological thinking, the fundamentals of their

(C) Siberian Federal University. All rights reserved

* Corresponding author E-mail address: varavina1982@mail.ru 
philosophy and nomadic world outlook, will always remain a hot topic.

Keywords: indigenous peoples of the Arctic, Northern nomads, Evens, Evenki, traditional world outlook, cultural heritage, traditional ornament, symbolical language of culture, ornament semantics.

DOI: 10.17516/1997-1370-2016-9-10-2525-2530.

Research area: ethnography, ethnology and anthropology.

Being one of the oldest components of culture, ornament forms the base of decorative applied art of any ethnos, embodying ancient traditions and values of the people. Indeed, this kind of art is closely connected to the traditional lifestyle, cultural and economic activity of the people, and forms one of the most permanent elements of an ethnic culture. Traditional ornament system of the small-numbered indigenous peoples of the North is remarkable with its stability, expressiveness and diversity of ornamental shapes and motives based on mythological thinking and a specific world outlook. Ornament is an integral part of both material and spiritual cultures. It plays an important role in the everyday life and ritual activity of the ethnos.

For the Northern peoples, ornament is a peculiar system of signs, partially substituting writing, accompanying every person in his life journey from birth to death. The figurative "language" of the Northern peoples' ornament is rich and multi-faceted, absorbing the experience of close interaction between man and nature.

Tungus ornament is one of the phenomena in the national culture of the Evens and Evenki, reflecting its originality and specific features. The main specificity of the Tungus ornament is the reflection of the nomadic culture, traditional lifestyle and original world outlook of the people. It is peculiar for its artistic, stylistic features, as well as sacral and semantic content. The ornamental motives were deemed sacral and acted as a protective amulet.

It is especially obvious in clothes and jewellery. Thus, every piece of clothes and ornament was intended to protect the soul from various negative powers. For instance, the protecting ornament on the headdress and the braid piece was made to protect the head soul; the pectoral ornament was made to protect the heart soul etc. Let us remark that the Evens and the Evenki believed that every person had more than one souls. According to their world outlook, some of those souls looked like the person's twin; moreover, there are separate souls of different body parts, such as the head, hands, feet etc. For example, Evenki called the head soul inikta. Based on this concept, traditional clothes of the peoples protected every part of body. Ornament as protection played a special role in it. In the traditional Even and Evenki costume, the chest area is decorated richer than any other, as it is considered to protect the chest. It is explained by the belief that the soul of the person lives in the heart or lungs. The headdress is also richly ornamented as it is believed to protect the head soul. The rich ornament on the footwear is protection from the spirits from the lower world that can penetrate into the human body through the feet [FDA, 2010; 2011; 2015].

It is interesting to remark that the pieces embroidered with reindeer neck hair locked its soul, protecting the owner from miseries and bad luck. According to the Evens and Evenki, animal soul lives in the neck hair (Saf'iannikova, 2007).

The burial clothes of the Evens called busek and that of the Evenki called khallasik was decorated richly and thoroughly. The busyk of the Berezovka Evens (burial costume) is a costume designed in a special way. As they believe, "the ornament on such clothes must demonstrate the whole life journey of the deceased". The material 
of the costume and the ornament consisted of certain parts of the reindeer fur, wool and skin. The only material permitted for use besides the reindeer fur was the fur of a squirrel. No parts of the costume could be intact: cross-shaped holes were cut in each and every one of them. It was not allowed to decorate the costume with bongydy (a copper circle or rectangle), as the Evens believed that it would make the transition into the after world harder (Kraski severnogo siianiia..., 2004). It is interesting to note, that the Evens decorated the tips of diurkule, or burial shoes, with a picture of a loon foot surrounded by stripes of black and white beads (Saf'iannikova, 2007).

Special attention should be paid to the protective amulets of the Evens and the Evenki: those are guarding amulets, talismans, family idols. They symbolically protected the soul of the person, guarding the family and providing future generations. The semantics of ritual amulets was tightly connected to the symbolic idea of birth, growth and creation. Doubtlessly, the sacral language of the ornament is of the greatest interest: for example, a silver circle on the crib back is a polysemic symbol in the spiritual culture of the North Tungus. The circle was associated with the sun and the cycle of human soul.

Generally, the traditional ornaments of the Evens and Evenki are similar both in the material and the motives. The ornaments are used to decorate various household utensils, clothes, bags, pouches, carpets, baby cribs, reindeer harness, different things of birch bark, bone, wood, metal. The ornament motives are strictly geometric. Border patterns are the favourite. According to S.V. Ivanov, "pictures of animals are not used as pattern elements" (Ivanov, 1963).

The major motives of the North Tungus' ornaments are stripes (stripe motives), various circular ornaments (simple and concentric circles, semicircles, circle with a dot), rectangles, squares etc. The stripe ornament is very wide-spread, especially among the Evens. It is produced in various ways: embroidered with deer hair and coloured threads, made of coloured beads, drawn with paint. The ornament of different circles (embroidered and beaded circles) are just as popular, occupying a very important place in the traditional art of the Evens and Evenki. These patterns are interpreted as signs of the sun, as well as symbols of other celestial bodies (FDA, 2010; 2011; 2015). It is also important to remark that circles (as well as stripes), concentric circles and circles with dots in the centre "serve as the main ethnic delimiters of the Tungus artistic culture" (Kocheshkov, 1997). Another ornament pattern popular among the Evens and the Evenki is a group of motives of rectangles, squares and rhombi, forming vertical and horizontal lines. Simple and complicated arch-like patterns (arches with rhombi and crosses) and triangles also belong to the most popular ornament motives (FDA, 2010; 2011; 2015).

The process of digging out little triangles on wooden objects and the ornaments made of such triangular hollows is called duktyke in the Even art. The hollows were often painted in black, and the remaining plains of the wood were white. Straight lines cut with a knife were called ugur (from $u g u$, "to cut a straight line"). Semicircles were called the same way as the action itself, or tynire, and an ornament of semicircles was called tynirek. The ornament also included two whorls, diolog ien (wether horn) and seli ien (literally, "mammoth horn", i.e. mammoth tusk). Their ends united into a single pattern. If the saddlebow was divided with a wide duktyke stripe in the middle, then lines curved up to the external lines were made; such lines were called saremukta / saremikta, "eyebrow". Sometimes the very middle of the saddlebow was lined with a sixfaceted hollowed out stripe, diur kirichi (literally, "dihedral"), with several rows of duktyke and a very schematic picture of a man (beie) made of 
lines, a head with a body, risen arms and spread legs (Vasilevich, 1969).

Flat ivory objects were ornamented with a knife or a compass (circles and semicircles). Combinations of lines and hollows made up a geometric pattern, with the element names the same as those of the ornament made on wood (Vasilevich, 1969).

Decoration of metal objects was relatively underdeveloped in the North Tungus culture, probably, because it was adopted from Russians and the Yakut. Geometric ornaments decorated spearheads, screwdrivers, reindeer harness parts, leather scrapers, metal jewellery, smoking pipes, and pendants of shaman costumes (Istoriia $\mathrm{i}$ kul'tura..., 2010).

The East Evenki (living East from the Olekma and the head of the Aldan) usually decorated birch bark objects with two-dot shaped imprints of a small reindeer claw horn (urun). The action itself was called dektekele-; the ornament was called dektekelevun; ornamented case bags were called dektek. The geometric ornament weaved with a thread was applied on the external edge of birch bark vessels with lids and on the lid edges (Vasilevich, 1969).

The general Tungus way of decoration of different fur things was combination of white and dark fur stripes. Sometimes, stripes of this or that colour on one edge were cut in the shape of purls (iktekepche), and then stripes of another colour were sewed on the same edge. In kumalanakh the Evenki, living East from the Lena and Baikal, ornamented the middle (the stripe used to connect to head skins) and the edges. The VitimoOlekmino Evenki also had rectangular carpets made of tur stripes constituting a geometric ornament (Vasilevich, 1969).
Things made of reindeer chamois were ornamented with straight flagellant stitches with white neck hair, whipstitched with tendon thread. The space between the flagellum stitches was painted with red (brow) and black paint (the Zeya, the Aldan, the Amur). Moreover, a little apart from each other, two beads (sym) were sewn on this coloured stripe. The stripes (both on footwear and the chamois caftan) constituted a certain pattern. This way of decoration called kereshme was typical of the Evenki residing near the Yenisei. The Evenki living East from the Yenisei to Lena, as well as the Transbaikal and some of the Amur Evenki, applied threads of coloured beads on the chamois, interchanged with coloured stripes of cotton cloth. The Evenki living East from the Olekma decorated chamois clothes with silk ornaments, filling the contour with buttonhole stitches. In the decorative art of the East Evenki a compulsory addition of women's round boxes and halters were chamois fringes or bunches of chamois strips (nelbi) interchanged with strings (chureptyn, churektu, chureptu) of different furs (Vasilevich, 1969).

So, the ornament culture of the North Tungus is rich and multi-faceted, preserving its original character. As an integral part of the material world, the ornament was included into the symbolic field of a culture. It played a connecting role between the material and spiritual world, assigning the object with a specific status and functions (e.g. protective function). A protective role in the Even and Evenki ornament was also played by colour symbolism. An ornament may be considered to be a symbolic "language" connected with a wide range of "texts", rituals and beliefs. It is a special type of "language" for the world outlook, the traditional culture of the ethnos.

\section{References}

Vasilevich, G.M. (1969) Evenki. Istoriko-etnograficheskie ocherki (XVIII - nachalo XX v.) [Evenki. Historical and Ethographic Essays (18 ${ }^{\text {th }}-$ early $20^{\text {th }}$ centuries)] Leningrad: Nauka, $304 \mathrm{p}$. 
Ivanov, S.V. (1963) Ornament narodov Sibiri kak istoricheskiy istochnik (po materialam XIXnachala XX v.). Narody Severa i Dal'nego Vostoka [Ornament of Siberian Peoples as a Historical Source (Based on Materials of the $19^{\text {th }}-$ Early $20^{\text {th }}$ Centuries). Peoples of the North and the Far East]. Moscow; Leningrad: USSR Academy Publishing House, 442 p.

Istoriia i kil'tura dal'nevostochnykh evenkov: istoriko-etnograficheskie ocherki [History and Culture of the Far East Evenki: Historical and Ethnographic Essays] (2010), edited by V.A. Turaev; Institute of History, Archaeology and Ethnography of the Peoples of the Far East of the Far East Branch of Russian Academy of Sciences. Saint Petersburg: Nauka, 334 p.

Kocheshkov, N.V. (1997) Tiurko-mongoly i tunguso-man'chzhury. Problemy istoriko-kul'turnykh sviazey na materiale narodnogo dekorativnogo iskusstva XIX-XX vv. [Turk-Mongols and TungusManchurians. Historical and Cultural Connection Issues Based on Folk Decorative Art of the $19^{\text {th }}-20^{\text {th }}$ Centuries]. Saint Petersburg: Nauka, 176 p.

Kraski severnogo siianiia v uzorakh masterits: (Prikladnoe iskusstvo evenov Berezovki) [Polar Lights in the Mistrisses' Patterns (Applied Art of the Berezovka Evens)] (2004) / Compiled by M.E. Robbek, In: Pamiatniki etnicheskoy kul'tury korennykh malochislennykh narodov Severa, Sibiri i Dal'nego Vostoka [Monuments of Ethnic Cultures of the Small-Numbered Indigenous Peoples of the North, Siberia and the Far East], Volume 4. Novosibirsk: Nauka, 88 p.

FDA, 2010 (Field data of the author, collected in Allaikhovsky District of Yakutia in 2010); FDA, 2011 (Field data of the author, collected in Kobiaysky District of Yakutia in 2011); FDA, 2015 (Field data of the author, collected in Verkhoyansky District of Yakutia in 2015).

Saf'iannikova, T. (2007) Ornamenty i ukrasheniia evenkov [Evenki Ornaments and Decorations]. Krasnoyarsk: Sibirskie promysly, 192 p.

\title{
Орнаментальное искусство
}

коренных народов Арктики:

\author{
традиции и современность
}

\section{(на примере эвенов и эвенков)}

\author{
Г.Н. Варавина \\ Институт гуманитарных исследований \\ и проблем малочисленных народов Севера СО РАН \\ Россия, 677027, Якутск, \\ Республика Саха (Якутия), ул. Петровского, 1
}

В статье рассматриваются орнаментальные традиции коренных народов Арктики. Дается общая типологическая характеристика традиционного орнамента северных тунгусов - эвенов и эвенков. Они испокон веков уникальные представители северных кочевых народов, являют собой северо-восточное подразделение собственно тунгусов, относятся к сибирскоманьчжурской этногенетической ветви. В проиессе длительного исторического развития северные народы создали множество памятников декоративного искусства, составляющих в настоящее время часть уникального культурного наследия цииркумполярного региона, внесших 
совокупный вклад в сокровищнищу мировой культуры. Циркумполярная культура кочевников развила разветвленную систему гармоничного существования природы и человека. Эти знания северных кочевников передавались из поколения в поколение через памятники культуры и искусства, которые являются уникальными образцами декоративно-прикладного искусства этноса. Образный «язык» орнамента северных народов богат и многогранен, вобрал в себя опыт взаимодействия человека с природой. Тунгусский орнамент - одно из явлений национальной культуры эвенов и эвенков, отразившее ее своеобразие и специфические черты. Специфика тунгусского орнамента заключается в том, что он выражение их кочевой культуры, традиционного образа жизни и своеобразной картины мира. Он отличается художественностилистическими особенностями и сакрально-семантическим содержанием. Их орнаментальные мотивы считались сакральныли, они были призваны выполнять функции оберега. Следует отметить, что орнаментика является одним из наиболее самобытных элементов этнической культуры, который подвержен изменениям в намного меньшей степени, чем предметы повседневного использования. Однако тунгусский орнамент, в частности эвенов и эвенков Якутии, остается малоизученной областью, которая не получила всестороннего и глубокого анализа, особенно в семиотическом и лингвистическом планах, поэтому эта работа поднимает действительно актуальную проблему. Кроме того, в условиях растущего интереса $\kappa$ культуре автохтонных этносов, их истории и ценностям традиционный орнамент возможно отнести к «сырьевым ресурсам будущуего». В настоящеее время широко распространяется сфера применения форм, композиций и элементов традиционной орнаментики в различных областях культурыл. Например, при создании товарных знаков, в дизайнерских и оформительских работах и т.д. Так, в Бурятском институте естественных наук создается компьютерная база данных традиционного орнамента монголоязычных народов, которая становится своеобразной энциклопедией символов, и с помощуью которой можно будет моделировать новые узоры, используя существующие прототипь. Поэтому традиционная орнаментика на современном этапе не исчерпала возможностей дальнейшего развития и сегодня. Важно отметить, что традиционная орнаментальная культура коренных малочисленных народов Севера и Сибири, в основе которой лежит мифологическое мылиение, мировоззрение кочевников, всегда остается актуальной темой.

Ключевые слова: коренные народы Арктики, северные кочевники, эвены, эвенки, традиционное мировоззрение, культурное наследие, традиционный орнамент, символический язык культуры, семантика орнамента.

Научная специиальность: 07.00.07 - этнография, этнология и антропология. 